ANATOLIY PAVLENKO

ANNA MARIA SLOWAK

Kielce University of Technology

e-mail: apavlenko@tu.kielce.pl
Manuscript submitted 2018.09.03 - revised 2018.10.15, initially accepted for publication 2019.05.24, published in September 2019

\title{
PHYSICO-CHEMICAL CHARACTERISTICS OF FUEL GAS MIXTURES
}

\section{CHARAKTERYSTYKA FIZYKOCHEMICZNA MIESZANEK GAZÓW PALIWOWYCH}

DOI: $10.30540 / \mathrm{sae}-2019-017$

\begin{abstract}
The article presents data on changes in physical and chemical properties of mixtures of generator gases with natural gas and the issue of the optimal ratio of these gases in the mixture. The results of research on the basic properties of flammable mixture of generator gases and natural gas are presented, on the basis of which the optimal composition of the mixture was proposed.
\end{abstract}

Keywords: properties of combustible gas mixtures, pyrolysis gas, artificial gas, combustion of gas, mixture, generator gas

Streszczenie

W artykule przedstawiono dane dotyczace zmian właściwości fizycznych i chemicznych mieszanin gazów generatorowych z gazem ziemnym oraz zagadnienie optymalnego stosunku tych gazów w mieszaninie. Przedstawiono wyniki badań podstawowych wtaściwości palnych mieszaniny gazów generatorowych i gazu ziemnego, na podstawie których zaproponowano optymalny sklad mieszaniny.

Słowa kluczowe: właściwości palnych mieszanek gazów, gaz pirolityczny, gaz sztuczny, spalanie mieszaniny gazów, gaz generatorowy

\section{INTRODUCTION}

Insufficient deposits of natural gas and other fossil fuels, as well as a significant share of natural gas in the thermal energy production process, lead to the need to address the problem of natural gas diversification and the wider use of renewable energy sources, including biomass energy. Generator gas can be the solution to this problem.

Direct combustion of solid biomass in many cases gives a positive economic effect, however, it is associated with expensive boiler house reconstruction, the need to provide space for fuel storage and environmental problems of fuel combustion. Generating and burning generator gas is a good alternative. There is also the problem of burning synthetic gases in a mixture with natural gas using the same gas burners.

\section{WPROWADZENIE}

Niewystarczające pokłady gazu ziemnego i innych paliw kopalnych, a także znaczny udział gazu ziemnego w procesie wytwarzania energii cieplnej prowadzą do konieczności rozwiązania problemu dywersyfikacji gazu ziemnego i szerszego wykorzystania odnawialnych źródeł energii, w tym energii biomasy. Gaz generatorowy może być rozwiązaniem tego problemu.

Bezpośrednie spalanie biomasy stałej w wielu przypadkach daje pozytywny efekt ekonomiczny, wiąże się to jednak z kosztowną przebudową kotłowni, potrzebą zapewnienia miejsca na składowanie paliwa oraz problemami środowiskowymi spalania paliw. Generowanie i spalanie gazu generatorowego jest dobrą alternatywą. Pojawia się również problem spalania gazów syntetycznych $\mathrm{w}$ mieszaninie $\mathrm{z}$ gazem ziemnym przy użyciu tych samych palników gazowych. 


\section{PURPOSE OF RESEARCH}

Investigation of the characteristics of the generator gas, natural gas and determination of their optimal share in the fuel mixture.

\section{SUBJECT OF RESEARCH}

The characteristics of the combustion process and the design of gas burners depend on the composition of the gas or combustible mixture and their physical and chemical properties. The main feature of generator gases is the change in their composition and characteristics during production. This results in a continuous change of important combustion efficiency features, such as:

- normal flame spread speed;

- volume of combustion products and secondary air demand for total gas combustion;

- stability, penetration and flame separation;

- temperature of combustion products, brightness of the flame and heat of combustion, composition of gases;

- enthalpy of combustion products, thermal power of the burner and heat recovery from the gas combustion device;

- characteristics of the fuel mixture.

Table 1 shows the average characteristics of natural gas and generator gas.

\section{CEL BADAŃ}

Badanie charakterystyki gazu generatorowego, gazu ziemnego i określenie optymalnego ich udziału w mieszance paliwowej.

\section{PRZEDMIOT BADAŃ}

Charakterystyka procesu spalania i konstrukcja palników gazowych zależą od składu gazu lub mieszaniny palnej i ich właściwości fizykochemicznych. Główną cechą gazów generatorowych jest zmiana ich składu i charakterystyki w czasie produkcji. Powoduje to ciągłą zmianę ważnych cech wydajnościowych spalania, takich jak:

- normalna prędkość rozprzestrzeniania się płomienia;

- objętość produktów spalania i zapotrzebowanie na powietrze wtórne do całkowitego spalenia gazu;

- stabilność, zjawisko przebicia i separacja płomienia;

- temperatura produktów spalania, jasność płomienia i ciepło spalania, skład gazów;

- entalpia produktów spalania, moc cieplna palnika i odzysk ciepła z urządzenia do spalania gazu;

- charakterystyka mieszanki paliwowej.

Tabela 1 pokazuje uśrednione charakterystyki gazu ziemnego i generatorowego.

Table 1. Comparative table of basic physical and chemical properties of natural and generator gases

Tabela 1. Tabela porównawcza podstawowych wtaściwości fizycznych i chemicznych gazu ziemnego i generatorowego

\begin{tabular}{|c|c|c|c|c|}
\hline No. & Indicator & Unit of measurement & Natural gas & Pyrolysis gas \\
\hline 1 & Lower heat of combustion $Q_{h}^{p}$ & $\mathrm{~kJ} / \mathrm{m}^{3}$ & 35895 & 5426 \\
\hline 2 & Theoretical air flow $V_{t}$ & $\mathrm{~m}^{3} / \mathrm{m}^{3}$ & 9.5 & 1 \\
\hline 3 & Volume of combustion products $V_{p z}$ at $a=1$ & $\mathrm{~m}^{3} / \mathrm{m}^{3}$ & 10.5 & 1.9 \\
\hline 4 & Maximum speed flame spread $u_{h}{ }^{\max }$ & $\mathrm{m} / \mathrm{s}$ & 0.37 & 1.03 \\
\hline 5 & Maximum velocity of flame propagation with ballast $\mathrm{u}_{\mathrm{h}}^{\max }{ }_{\text {bal }}$ & $\mathrm{m} / \mathrm{s}$ & 0.3677 & 1.297 \\
\hline \multirow{2}{*}{6} & Burning limits: lower $L_{h}$ & $\%$ vol. & 5.005 & 19.11 \\
\hline & upper $L_{b}$ & $\%$ vol. & 15.05 & 72.4 \\
\hline \multirow{2}{*}{7} & Excess air ratio in within the limits of ignition: on the lower limit $a_{h}$ & frequencies & 1.994 & 4.163 \\
\hline & on the upper limit $a_{b}$ & frequencies & 0.593 & 0.375 \\
\hline 8 & Content of combustible gas mixed with air provided stoichiometric combustion reaction $\mathrm{L}_{\mathrm{ct}}$ & $\%$ vol. & 9.5 & 45.07 \\
\hline 9 & Gas burning temperature $t_{\text {upper }}$ & ${ }^{\circ} \mathrm{C}$ & 2763.7 & 1674.6 \\
\hline
\end{tabular}


We observe a wide range, higher speed of flame spread and lower heat of combustion of the generator gas compared to natural gas despite the higher content of $\mathrm{H}_{2}$ in the generator gas (up to $25 \%$ volume) and $\mathrm{CO}$ (up to $26 \%$ volume). The lower combustion temperature is conditioned by gas pollution $-\mathrm{CO}_{2}$ (up to $15 \%$ vol.) and $\mathrm{N}_{2}$ (up to $50 \%$ by volume).

The average natural gas composition differs from the genarator gas with higher combustion heat (up to $23 \mathrm{MJ} / \mathrm{m}^{3}$ ), a significant amount of $\mathrm{CH}_{4}$ as well as impurities (Table 2).

\begin{tabular}{|l|l|l|l|l|l|l|}
\hline Component name & $\mathrm{CO}_{2}$ & $\mathrm{O}_{2}$ & $\mathrm{CH}_{4}$ & $\mathrm{H}_{2}$ & $\mathrm{~N}_{2}$ & $\mathrm{H}_{2} \mathrm{~S}$ \\
\hline Content of components, \% vol. & 31.7 & 0.4 & 67.2 & 0.1 & 0.5 & 0.1 \\
\hline
\end{tabular}

Table 3 shows the characteristics of natural gas, the composition of which varies by months of the year.
Obserwujemy szeroki zakres, większą prędkość rozprzestrzeniania się płomienia oraz mniejsze ciepło spalania gazu generatorowego $\mathrm{w}$ porównaniu $\mathrm{z}$ gazem ziemnym pomimo większej zawartości $\mathrm{H}_{2}$ w gazie generatorowym (do $25 \%$ objętości) i CO (do $26 \%$ objętości). Niższa temperatura spalania uwarunkowana jest zanieczyszczeniami gazu $-\mathrm{CO}_{2}$ (do $15 \%$ obj.) i $\mathrm{N}_{2}$ (do $50 \%$ obj.). Średni skład gazu ziemnego różni się od gazu generatorowego wyższym ciepłem spalania (do $23 \mathrm{MJ} / \mathrm{m}^{3}$ ), znaczną ilość $\mathrm{CH}_{4}$, a także zanieczyszczeniami (tabela 2 ).

Table 2. The average composition of biogas [1] Tabela 2. Średni sktad gazu generatorowego [1]

Tabela 3 pokazuje charakterystykę gazu ziemnego, którego skład zmienia się w zależności od miesiąca w roku.

Table 3. Some characteristics of natural gas

Tabela 3. Niektóre właściwości gazu ziemnego

\begin{tabular}{|c|c|c|c|c|c|}
\hline Characteristics of gas & January & February & March & June & August \\
\hline Heat of combustion $Q_{h}{ }^{p}, \mathrm{kcal} / \mathrm{m}^{3}$ & 10138 & 9250 & 10656 & 10660 & 8390 \\
\hline Theoretical need of the air $V_{0^{\prime}} \mathrm{m}^{3} / \mathrm{m}^{3}$ & 11.1 & 10.1 & 11.6 & 11.5 & 8.9 \\
\hline Maximum content $\mathrm{CO}_{2}{ }^{\max }$ in products of combustion $\%$ obj. & 13.1 & 12.9 & 13.2 & 13.3 & 12.7 \\
\hline Fuel gas density $\rho, \mathrm{kg} / \mathrm{m}^{3}$ & 0.88 & 0.78 & 0.92 & 0.91 & 0.68 \\
\hline The upper limit of the flare $L^{b}$ & 18.7 & 19.8 & 17.9 & 18.5 & 22.4 \\
\hline Excess air ratio at the upper limit ignition $a_{1}^{\max }$ & 0.392 & 0.403 & 0.395 & 0.381 & 0.389 \\
\hline The content of hydrogen in the gas $\mathrm{H}_{2^{\prime}} \%$ & 42.4 & 44.8 & 37.5 & 42.2 & 54.5 \\
\hline Combustion temperature $\mathrm{t}^{\circ}{ }^{\circ} \mathrm{C}$ & 2093 & 2123 & 2185 & 2274 & 1755 \\
\hline
\end{tabular}

The heat of natural gas burning is much higher than the genarator gas due to the content of heavy hydrocarbons. The main feature of artificial gases is the high content of ballast $\left(\mathrm{CO}_{2}\right.$ and $\left.\mathrm{N}_{2}\right)$ in their composition, which worsens the properties of combustible fuel.

Most gas combustion devices that are found in the literature and catalogs of burners $[1,4]$ have been designed and manufactured to operate on natural gas. The assessment of their ability to work on other types of gaseous fuels or the assessment of gas interchangeability is carried out according to various criteria, but none of them is completely reliable and can not fully assess the possibility of ensuring stability for all types of gaseous fuel. The characteristics of the burner's operation change significantly when
Ciepło spalania gazu ziemnego jest znacznie większe niż gazu pirolitycznego ze względu na zawartość ciężkich węglowodorów. Stężenie wodoru w gazie ziemnym jest praktycznie takie samo jak w pirolitycznym. Główną cechą gazów sztucznych jest wysoka zawartość balastu $\left(\mathrm{CO}_{2} \mathrm{i} \mathrm{N}_{2}\right)$ w ich składzie, który pogarsza właściwości paliwa palnego.

Większość urządzeń do spalania gazu, które znajdują się w literaturze i katalogach palników [1, 4], zostały zaprojektowane i wyprodukowane do pracy na gazie ziemnym. Ocena ich zdolności do pracy przy innych rodzajach paliw gazowych lub ocena zamienności gazów jest przeprowadzana według różnych kryteriów, ale żadne z nich nie jest całkowicie niezawodne i nie może w pełni ocenić możliwości zapewnienia stabilności przy wszystkich rodzajach paliwa 
switching from one gas to another. These are such features as:

- ensuring constant thermal power of the burner and thermal power of the installation during the transition from one gas to another, $N=$ const;

- stable burner's operation, no breakdown phenomena and flame separation in the entire range of the burner adjustment;

- the constancy of the composition of toxic compounds of combustion products $\left(\mathrm{CO}, \mathrm{NO}_{\mathrm{x}}\right.$, nitrogen oxides, soot, etc.);

- immutability of flame propagation speed.

Essentially, flammable gases can be called interchangeable, if one gas can be replaced with another without additional adjustment of the burner.

The reason for the existence of different criteria of interchangeability is that they are not obtained on the basis of basic rights, but are empirical. Gases as well as burner constructions have various limitations.

Thus, the Wobbe criterion essentially assesses the possibility of ensuring constant thermal power of the unit in the transition from one combustible gas to another:

- simple Wobbe criterion:

$$
\begin{gathered}
W o_{1}=W o_{2}=\cdots W o_{n}=\text { const } \pm 5 \% \\
\frac{Q_{H 1}^{p}}{\sqrt{\rho_{1}}}=\frac{Q_{H 2}^{p}}{\sqrt{\rho_{2}}}=\cdots=\frac{Q_{H n}^{p}}{\sqrt{\rho_{n}}}=\text { const } \pm 5 \%
\end{gathered}
$$

where: $W o_{1}, W o_{2}, W o_{n}$ are simple Wobbe criteria, which are determined for flammable gases based on the combustion heat $\left(Q_{p}\right)$ and the relative density $\left(\rho_{i}\right)$ under normal or standard conditions; the extended Wobbe criterion estimates the possibility of using the same gas combustion device, provided that different gas pressure $\left(P_{i}\right)$ is maintained in front of the burner:

$$
\begin{aligned}
& Q_{H 1}^{p} \sqrt{\frac{P_{1}}{\rho_{1}}}=Q_{H 2}^{p} \sqrt{\frac{P_{2}}{\rho_{2}}}=\cdots \\
& =Q_{H n}^{p} \sqrt{\frac{P_{n}}{\rho_{n}}}=\text { const } \pm 5 \%
\end{aligned}
$$

In Great Britain, the equivalent hydrocarbons method is used to determine exchangeability. Weaver's criterion takes into account the differences in the normal velocity of the flame spread, as well as the stability of flame separation and explosion of various gases. The assessment of boundaries and completeness of gas combustion is carried out using the French exchange rate method. One of these gazowego. Charakterystyka pracy palnika znacznie zmienia się w przypadku przejścia z jednego gazu na drugi. Są to takie cechy jak:

- zapewnienie stałości mocy cieplnej palnika i mocy cieplnej instalacji podczas przejścia z jednego gazu do drugiego, $N=$ const;

- stabilność pracy, brak zjawiska przebicia i separacja płomienia w całym zakresie regulacji palnika;

- niezmienność składu toksycznych związków produktów spalania $\left(\mathrm{CO}, \mathrm{NO}_{\mathrm{x}}\right.$, tlenków azotu, sadzy itp.);

- niezmienność prędkości rozprzestrzeniania się płomienia.

Zasadniczo gazy palne mogą być nazwane wymiennymi, jeżeli jeden gaz może być zastąpiony innym bez dodatkowej regulacji palnika.

Powodem istnienia różnych kryteriów zamienności jest to, że nie są one uzyskiwane na podstawie podstawowych praw, ale są empiryczne. Gazy, a także konstrukcje palników mają różne ograniczenia. Zatem kryterium Wobbego zasadniczo ocenia możliwość zapewnienia stałej mocy cieplnej jednostki w przejściu z jednego palnego gazu do drugiego: - proste kryterium Wobbego:

$$
\begin{gathered}
W o_{1}=W o_{2}=\cdots W o_{n}=\text { const } \pm 5 \% \\
\frac{Q_{H 1}^{p}}{\sqrt{\rho_{1}}}=\frac{Q_{H 2}^{p}}{\sqrt{\rho_{2}}}=\cdots=\frac{Q_{H n}^{p}}{\sqrt{\rho_{n}}}=\text { const } \pm 5 \%
\end{gathered}
$$

gdzie: $W o_{1}, W o_{2}, W o_{n}$ są wartościami, które określa się dla gazów palnych na podstawie ciepła spalania $\left(Q_{p}\right)$ i gęstości względnej $\left(\rho_{i}\right)$ w warunkach normalnych lub standardowych; rozszerzone kryterium Wobbego szacuje możliwość zastosowania tego samego urządzenia do spalania gazu, pod warunkiem, że przed palnikiem utrzymuje się różne ciśnienie gazu $\left(P_{i}\right)$ :

$$
\begin{aligned}
& Q_{H 1}^{p} \sqrt{\frac{P_{1}}{\rho_{1}}}=Q_{H 2}^{p} \sqrt{\frac{P_{2}}{\rho_{2}}}=\cdots \\
& =Q_{H n}^{p} \sqrt{\frac{P_{n}}{\rho_{n}}}=\text { const } \pm 5 \%
\end{aligned}
$$

W Wielkiej Brytanii do określenia wymienności służy metoda równoważnych węglowodorów. Kryterium Weavera uwzględnia różnice w normalnej prędkości rozprzestrzeniania się płomienia, a także stabilność separacji i wybuchu płomienia różnych gazów. Ocenę granic i kompletność spalania gazów przeprowadza się za pomocą francuskiej metody wskaźników zamienności. Jednym z tych wskaźni- 
indicators is the hydrogen index in the mixture. It should not be greater than $10 \%$ of the volume [4].

\section{RESULTS}

The wide composition spectrum of generator gas leads to the expansion of the range between the lower and upper combustion limits and complicates the stable combustion process without penetration and separation in the burner. The gas mixture becomes flammable in a wide range of concentrations.

Thus, clean generator gas has an ignition limit of $\alpha \mathrm{n}=4.15$ and $\alpha \mathrm{v}=0.375, \Delta \alpha=3.775$ (Figure 1). With such a wide range of inflammatory values, it is almost impossible to ensure stable combustion without flame explosion in kinetic burners. Increasing the share of natural gas in the mixture can significantly reduce the range of the flames and allow combustion of the gas mixture in the burners. For pure natural gas, the flammability limits are: $\alpha \mathrm{n}=2, \alpha \mathrm{v}=0.59, \Delta \alpha=1.41$ (Figure 1).

Figures 2 and 3 show graphs of changes in the content of a combustible mixture within the limits of ignition and changes in the normal flame spread coefficient depending on the proportion of natural gas in the mixture.

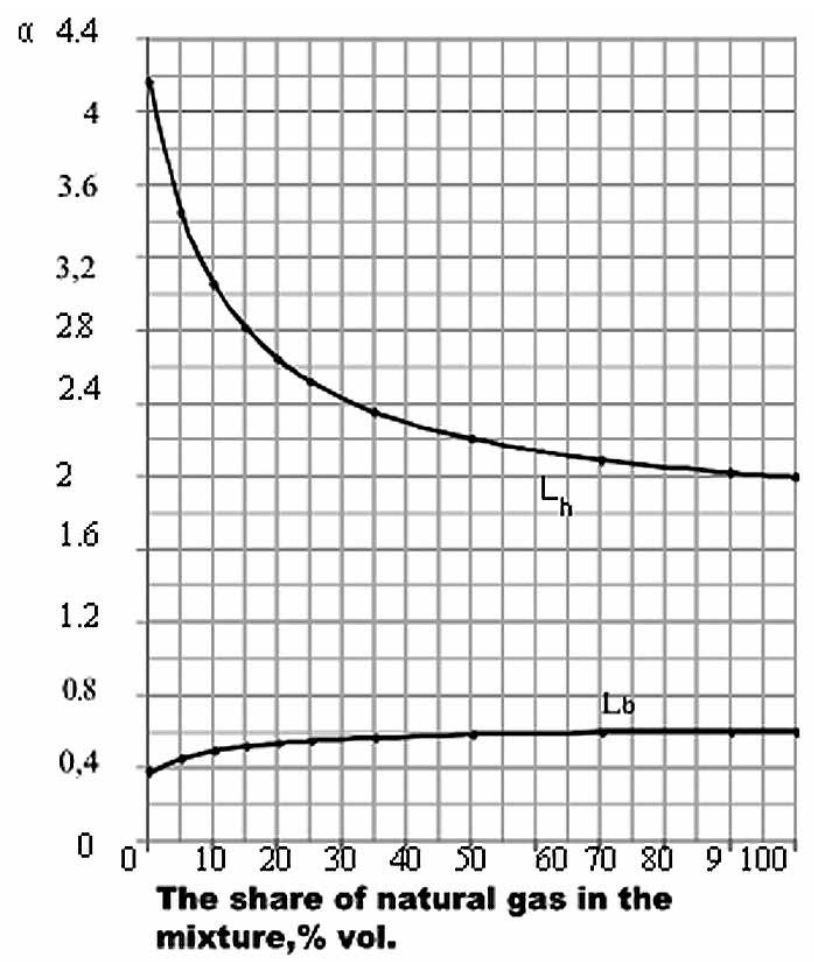

Fig. 1. Coefficients of excess air at the lower and upper limits of ignition

Rys. 1. Współczynniki nadmiaru powietrza przy dolnej i górnej granicy zapłonu ków jest wskaźnik wodoru w mieszaninie, nie powinien on być większy niż 10\% objętości [4].

\section{WYNIKI BADAŃ}

Szerokie spektrum składu gazów generatorowych prowadzi do rozszerzenia zakresu pomiędzy dolną i górną granicą spalania i komplikuje stabilny proces spalania bez przebicia i separacji w palniku. Mieszanina gazu staje się łatwopalna w szerokim zakresie stężeń.

Zatem czysty gaz generatorowy ma granice zapłonu od $\alpha \mathrm{n}=4,15 \mathrm{i} \alpha \mathrm{v}=0,375, \Delta \alpha=3,775$ (rys. 1). Przy tak szerokiej gamie wartości zapalnych prawie niemożliwe jest zapewnienie stabilnego spalania bez wybuchu płomienia w palnikach kinetycznych. Zwiększenie udziału gazu ziemnego w mieszaninie może znacznie zmniejszyć zasięg płomieni i umożliwić spalanie mieszaniny gazów w palnikach. Dla czystego gazu ziemnego granice palności są następujące: $\alpha \mathrm{n}=2, \alpha \mathrm{v}=0,59, \Delta \alpha=1,41$ (rys. 1).

Na rysunkach 2 i 3 przedstawiono wykresy dotyczące zmiany zawartości w mieszaninie palnej w granicach zapłonu i zmiany normalnego współczynnika rozprzestrzeniania się płomienia w zależności od proporcji gazu ziemnego w mieszaninie.

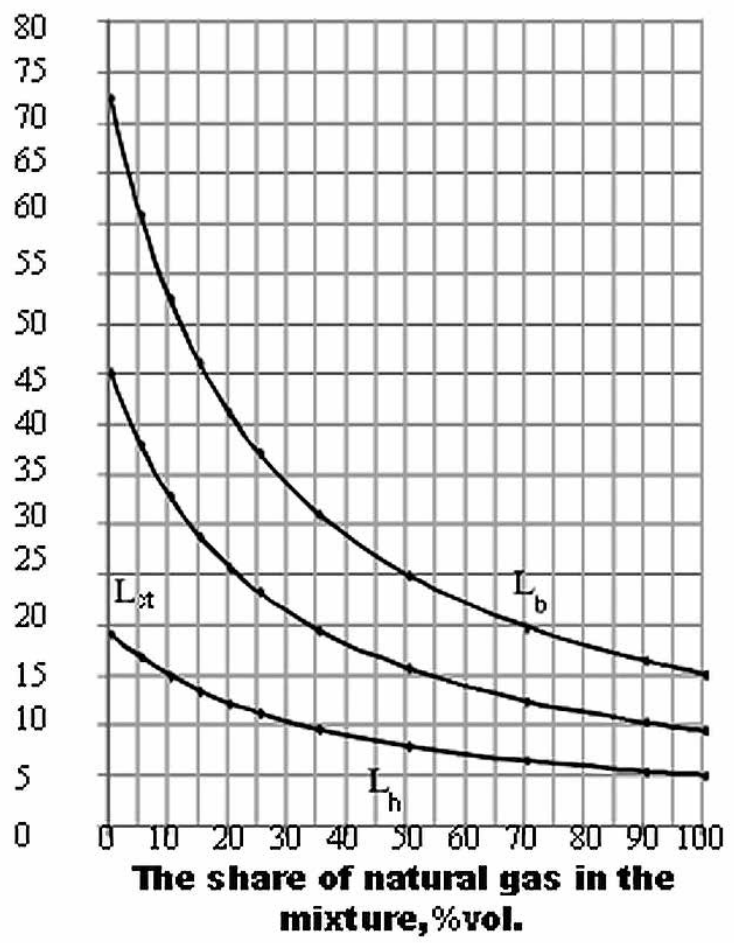

Fig. 2. Gas content at lower and upper limit of ignition and stoichiometric combustion, \% vol

Rys. 2. Zawartość gazu przy dolnej i górnej granicy zapłonu i spalaniu stechiometrycznym, \% objętości 


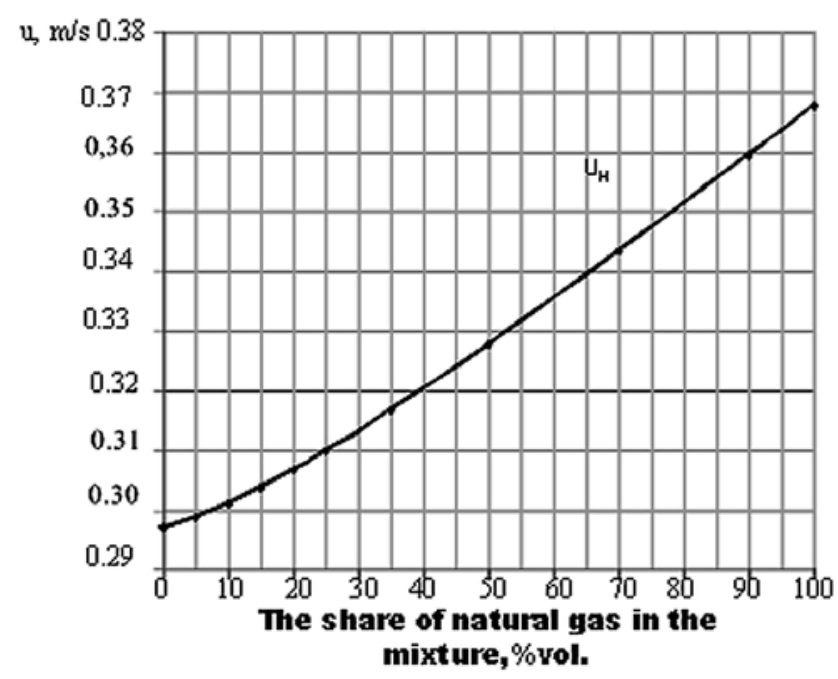

The change of gas density is a significant influence on the burners. It changes the loss of gas passing through the nozzle of the burner, which reduces the gas flow rate through the fire holes of the burners, therefore it changes the aerodynamic conditions of the gas mixture with the air blown in and affects the completeness of combustion and the heat output of the burner.

Thus, when the density of the gas changed from $0.5 \mathrm{~kg} / \mathrm{nm}^{3}$ to $1.2 \mathrm{~kg} / \mathrm{nm}^{3}$, the gas consumption decreased from $48 \mathrm{~m}^{3} / \mathrm{h}$ to $30 \mathrm{~m}^{3} / \mathrm{h}$ (the gas pressure in front of the nozzle was $200 \mathrm{kPa}$ ). The influence of gas density and heat of combustion is inversely proportional to the heat output of the burner.

To a certain extent, the dependance on density and gas combustion heat can be used to compensate for optimal combustion conditions, which makes it possible to balance gases. With significant differences in gas density, the amount of heat released in the combustion process is greater. Changes in the composition of natural gas in the density range from $0.6 \mathrm{~kg} / \mathrm{nm}^{3}$ to $0.78 \mathrm{~kg} / \mathrm{nm}^{3}$ have practically no effect on the amount of thermal power of the burner but with the increase of gas density from $0.8 \mathrm{~kg} / \mathrm{nm}^{3}$ to $1.2 \mathrm{~kg} / \mathrm{nm}^{3}$ due to the lower proportion of hydrogen in the gas, the amount of heat increases at $19 \%$.

Studies have shown that for the discussed criteria, generator gases are not interchangeable with natural gas. Combustion of gases with variable amount of hydrogen leads to unstable combustion, therefore the value of thermal energy obtained is unstable. The criterion for differences in the heat transfer process may be the ratio of the amount of carbon to hydrogen in the $\mathrm{Cp} / \mathrm{Hp}$ combustible gas composition, which affects the flame temperature (Figure 4).
Fig. 3. Normal flame propagation speed, $\mathrm{m} / \mathrm{s}$ Rys. 3. Normalna prędkość propagacji płomienia, $\mathrm{m} / \mathrm{s}$

Na działanie palników istotny wpływ ma zmiana gęstości gazu. Powoduje ona zmianę strat gazu przechodzącego przez dyszę palnika, co zmniejsza szybkość przepływu gazu przez otwory ogniowe palników, dlatego zmienia warunki aerodynamiczne mieszaniny gazu z wdmuchiwanym powietrzem i wpływa na kompletność spalania i moc cieplna palnika. Zatem gdy gęstość gazu zmieniła się z $0,5 \mathrm{~kg} / \mathrm{nm}^{3}$ do $1,2 \mathrm{~kg} / \mathrm{nm}^{3}$ zużycie gazu zmniejszyło się z $48 \mathrm{~m}^{3} / \mathrm{h}$ do $30 \mathrm{~m}^{3} / \mathrm{h}$ (ciśnienie gazu przed dyszą wynosiło $200 \mathrm{kPa}$ ). Wartość gęstości i ciepła spalania gazu jest odwrotnie proporcjonalne do wartości mocy cieplnej palnika.

W pewnym zakresie zależność od gęstości i ciepła spalania gazu można wykorzystać do kompensacji uzyskania optymalnych warunków spalania co stwarza możliwość dla zrównoważenia gazów. Przy znacznych różnicach $\mathrm{w}$ gęstościach gazów, ilość ciepła wydzielonego $\mathrm{w}$ procesie spalania jest większa. Zmiany w składzie gazu ziemnego w zakresie gęstości od $0,6 \mathrm{~kg} / \mathrm{nm}^{3}$ do $0,78 \mathrm{~kg} / \mathrm{nm}^{3}$ praktycznie nie mają wpływu na ilość mocy cieplnej palnika ale wraz ze wzrostem gęstości gazu od $0.8 \mathrm{~kg} / \mathrm{nm}^{3}$ do $1.2 \mathrm{~kg} / \mathrm{nm}^{3} \mathrm{z}$ powodu mniejszego udziału wodoru w gazie, ilość ciepła zwiększa się o 19\%.

Badania wykazały, że dla omówionych kryteriów gazy generatorowe nie są wymienne $\mathrm{z}$ gazem ziemnym. Spalanie gazów z zmienną ilością wodoru prowadzi do niestabilnego spalania dlatego wartość uzyskiwanej energii cieplnej jest niestabilna. Kryterium różnic $\mathrm{w}$ procesie wymiany ciepła może być stosunek ilości węgla do wodoru w składzie gazu palnego $\mathrm{Cp} / \mathrm{Hp}$, który wpływa na temperaturę płomienia (rys. 4). 


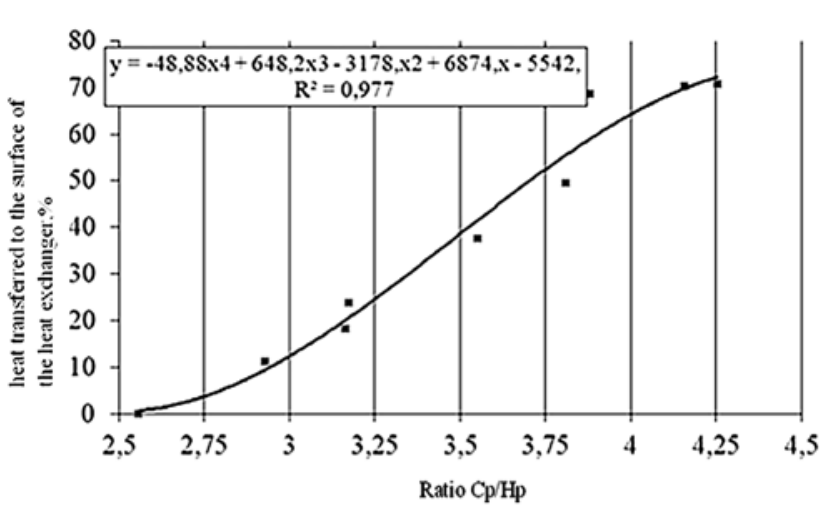

Decreasing the $\mathrm{Cp} / \mathrm{Hp}$ ratio leads to a reduction in the amount of heat received by the heating surfaces and to an increase in the temperature of the exhaust gas. It results from the effect of soot, which arises in the intermediate stages of burning in the flame, on the transmission of radiation heat.

Figure 5 shows the effect of hydrogen content in the composition of the artificial gas on the ratio $\mathrm{Cp} / \mathrm{Hp}$.

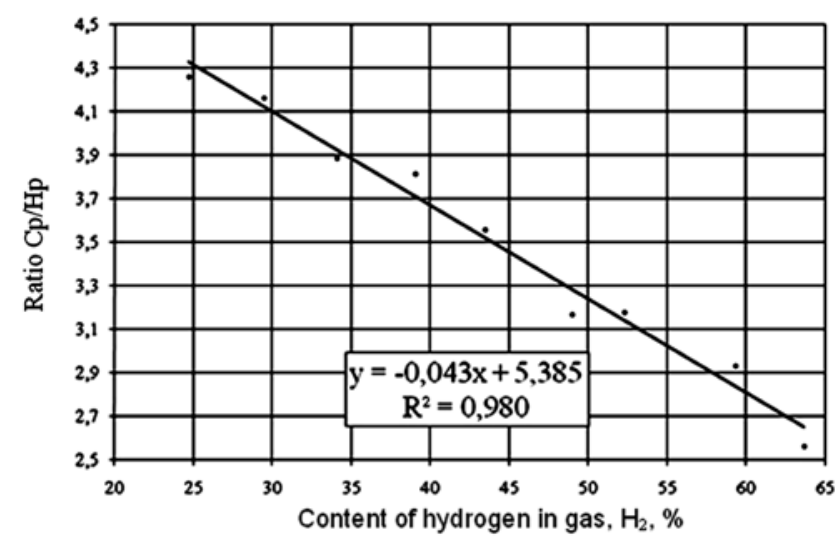

\section{CONCLUSIONS}

The tests have shown that getting the interchangeability conditioned by the criterion (Vobbe) is possible only when the natural gas with the generator one is pre-mixed. The share of the generator gas in such a mixture should not exceed $6-11 \%$ of the volume. Generator gas can not replace natural gas as a natural alternative. However, it is a source of renewable energy.

The use of generator gases and other synthetic gases whose criteria for interchangeability with natural gas are not within acceptable limits is not possible. Therefore, it is not possible to quickly switch from one type of gaseous fuel to another and to realize the benefits resulting from the use of gaseous fuel compared to the benefits of using solid fuels.
Fig. 4. Effect of gas composition on heat emission in the combustion space.

Rys. 4. Wptyw sktadu gazu na emisje ciepla w przestrzeni spalania

Zmniejszenie stosunku $\mathrm{Cp} / \mathrm{Hp}$ prowadzi do zmniejszenia ilości ciepła odbieranego przez powierzchnie grzewcze i do zwiększenia temperatury gazów spalinowych. Wynika to z wpływu sadzy, która powstaje $\mathrm{w}$ pośrednich stadiach spalania $\mathrm{w}$ płomieniu, na przenikanie ciepła promieniowania.

Rysunek 5 pokazuje wpływ zawartości wodoru w składzie gazu sztucznego na stosunek $\mathrm{Cp} / \mathrm{Hp}$.

Fig. 5. The effect of the amount of hydrogen in the flammable gas on the ratio $\mathrm{Cp} / \mathrm{Hp}$ in the elemental gas composition Rys. 5. Wplyw ilości wodoru w gazie palnym na stosunek $\mathrm{Cp} / \mathrm{Hp}$ w elementarnej kompozycji gazowej

\section{PODSUMOWANIE}

Badania wykazały, że uzyskanie zamienności warunkowane kryterium (Vobbego) jest możliwe tylko wtedy, gdy wstępnie zostanie zmieszany gaz ziemny $\mathrm{z}$ generatorowym. Udział gazu generatorowego $\mathrm{w}$ takiej mieszaninie nie powinien przekraczać 6-11\% objętości. Gaz generatorowy nie może zastąpić gazu ziemnego, stanowiąc naturalną alternatywę. Jest jednak źródłem energii odnawialnej.

Zastosowanie gazów generatorowych i innych gazów syntetycznych, których kryteria zamienności $\mathrm{z}$ gazem ziemnym nie są $\mathrm{w}$ dopuszczalnych granicach, nie jest możliwe. W związku z tym nie ma możliwości szybkiego przejścia z jednego rodzaju paliwa gazowego na inne i realizacji korzyści wynikających $\mathrm{z}$ zastosowania paliwa gazowego $\mathrm{w}$ porównaniu do korzyści wykorzystania paliw stałych. 


\section{REFERENCES}

[1] Tao Wang Zhenmin, Luoa Hu Wena, Fangming Chen Jun, Deng Jingyu Zhaoa, Zhengchao Guob Jingjing, Lina Kai Kang, Weifeng Wang: Effects of flammable gases on the explosion of CH4 in air, "Journal of Loss Prevention in the Process Industries", Vol. 49, Part B, September 2017, pp. 183-190.

[2] Forced Draft Burner handbook. Rielló S.p.A. Legnago - Italy, 2001, p. 171.

[3] Zhen H.S., Leung C.W., Cheung C.S., Huang Z.H.: Combustion characteristic and heating performance of stoichiometric biogas-hydrogen-air flame, "International Journal of Heat and Mass Transfer", Vol. 92, January 2016, pp. 807-814.

[4] Natural gas - Quality designation: EN ISO 13686. - Introduced 2007-09-01. - W.: Austrian Standards Institute, 2007, p. 48.

\section{Acknowledgments:}

The work was financed by Kielce University of Technology, part of the statutory work No. 05.0.08.00/2.01.01.01.0000 MNSP.IKFB.18.001

\section{Podziękowania:}

Praca była finansowana przez Politechnikę Świętokrzyska, w ramach pracy statutowej $n r$ 05.0.08.00/2.01.01.01.0000 MNSP.IKFB.18.001 